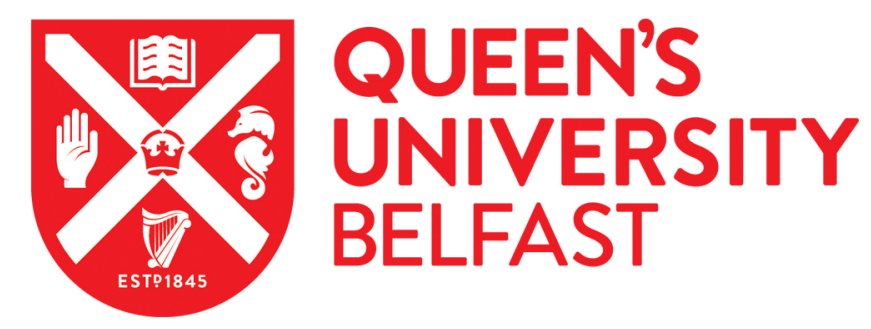

\title{
Effects of non-flooded mulching cultivation on crop yield, nutrient uptake and nutrient balance in rice-wheat cropping systems
}

Liu, X. J., Wang, J. C., Lu, S. H., Zhang, F. S., Zeng, X. Z., Ai, Y. W., Peng, S. B., \& Christie, P. (2003). Effects of non-flooded mulching cultivation on crop yield, nutrient uptake and nutrient balance in rice-wheat cropping systems. Field Crops Research, 83(3), 297-311. https://doi.org/10.1016/S0378-4290(03)00079-0

Published in:

Field Crops Research

Queen's University Belfast - Research Portal:

Link to publication record in Queen's University Belfast Research Portal

\section{General rights}

Copyright for the publications made accessible via the Queen's University Belfast Research Portal is retained by the author(s) and / or other copyright owners and it is a condition of accessing these publications that users recognise and abide by the legal requirements associated with these rights.

Take down policy

The Research Portal is Queen's institutional repository that provides access to Queen's research output. Every effort has been made to ensure that content in the Research Portal does not infringe any person's rights, or applicable UK laws. If you discover content in the Research Portal that you believe breaches copyright or violates any law, please contact openaccess@qub.ac.uk. 


\title{
Effects of non-flooded mulching cultivation on crop yield, nutrient uptake and nutrient balance in rice-wheat cropping systems
}

\author{
X.J. Liu ${ }^{\mathrm{a}}$, J.C. Wang ${ }^{\mathrm{a}}$, S.H. Lu ${ }^{\mathrm{a}, \mathrm{b}}$, F.S. Zhang ${ }^{\mathrm{a}, *}$, X.Z. Zeng ${ }^{\mathrm{a}, \mathrm{b}}$, \\ Y.W. Ai ${ }^{a}$, S.B. Peng ${ }^{\mathrm{a}, \mathrm{c}}$, P. Christie ${ }^{\mathrm{a}, \mathrm{d}}$ \\ ${ }^{a}$ Department of Plant Nutrition, KLPSI-MOE, China Agricultural University, Beijing 100094, China \\ ${ }^{\mathrm{b}}$ Institute of Soils and Fertilizers, Sichuan Academy of Agricultural Sciences, Chengdu 610066, China \\ ${ }^{\mathrm{c}}$ International Rice Research Institute, P.O. Box 7777, Manila, Philippines \\ ${ }^{\mathrm{d}}$ Agricultural and Environmental Science Department, Queen's University Belfast, Belfast BT9 5PX, UK
}

Received 5 October 2002; received in revised form 8 March 2003; accepted 4 April 2003

\begin{abstract}
A field experiment on a sandy loam was conducted to evaluate the effects of non-flooded mulching cultivation on the productivity, nutrient uptake and nutrient balance in rice-wheat $(\mathrm{R}-\mathrm{W})$ cropping systems in Chengdu flood plain, southwest China over a 3-year period. Plastic film mulching (PM) resulted in 12\% higher average yield of rice while wheat straw mulching (SM) led to $14 \%$ lower average yield of rice compared with lowland rice under traditional flooding (TF). Biomass accumulation and nutrient uptake followed similar trends to grain yield. Changes in soil temperature in relation to root growth and nutrient uptake were likely to be the major factor responsible for the changes in rice yields under non-flooded mulching cultivation. Compared with TF, PM of preceding rice did not affect the grain yield of wheat, whereas SM of preceding rice resulted in comparable grain yields of wheat at a lower $\mathrm{N}$ rate $\left(60 \mathrm{~kg} \mathrm{~N} \mathrm{ha}^{-1}\right)$ in the wheat season. The system productivity (total yield of rice + wheat) in PM was similar to that of TF and higher than that of SM. The yield decline in rice, however, could be partly compensated by the yield increase in wheat following rice, particularly at lower $\mathrm{N}$ rates. Apparent nutrient budgets showed positive nitrogen $(\mathrm{N})$ and phosphorus $(\mathrm{P})$ balances but negative potassium $(\mathrm{K})$ balance in the TF and non-flooded mulching $\mathrm{R}-\mathrm{W}$ systems. Compared with TF, PM led to lower NPK balance due to more nutrient removal by crops while SM led to greater NPK balance due to more nutrient inputs from straw but less nutrient removal by crops. After 3 years soil organic carbon (OC) and total nitrogen (TN) were not significantly altered by PM and SM but soil Olsen-P (AP) and exchangeable K (EK) were significantly increased by SM compared with TF. The changes in soil properties under non-flooded mulching cultivation initially reflected the nutrient balances in R-W systems. In conclusion, non-flooded mulching cultivation as PM and SM could be applied to R-W systems in southwest China but nutrient (especially N) management should be optimized in the two systems.
\end{abstract}

(C) 2003 Elsevier Science B.V. All rights reserved.

Keywords: Rice-wheat cropping system; Non-flooded mulching cultivation; System productivity; Nutrient uptake and balance

Abbreviations: TF, traditional flooding; PM, plastic film mulching; SM, wheat straw mulching; R-W, rice-wheat; N, nitrogen; P, phosphorus; K, potassium; M, mulching; DAT, days after transplanting; DAS, days after sowing; OC, organic carbon; TN, total nitrogen; AP, available (Olsen-) phosphorus; EK, exchangeable potassium

*Corresponding author. Tel.: +86-10-62892499; fax: +86-10-62893539.

E-mail address: zhangfs@cau.edu.cn (F.S. Zhang). 


\section{Introduction}

Rice-wheat (R-W) cropping systems are practised in south and east Asia within sub-tropical to warmtemperate climatic zones (Timsina and Connor, 2001). In China, these systems are used mainly in an area of 13 million ha in the Yangtze River Basin (Zheng, 2000), where seasonal shortage of freshwater often limits the production of the systems. Among all crops, rice consumed about $90 \%$ of total irrigation water (Bhuiyan, 1992). On the other hand, lowland rice is one crop that offers great potential to save irrigation water because its physiological water requirement $\left(4500 \mathrm{~m}^{3}\right.$ water ha $\left.{ }^{-1}\right)$ is much less than its actual water consumption and is equivalent to that of some upland crops (Wu and Xie, 1985; Guerra et al., 1998; $\mathrm{Si}, 2000)$. Numerous water efficient irrigation regimes for rice have therefore been tested (Mao, 2001) but they are difficult to apply and require large amounts of irrigation water during the rice growing season. Thus, plastic film mulching (PM) has been adopted and developed as a new rice cultivation technique in many regions of China since the 1980s (Zhao and Xiao, 1982; Peng et al., 1999) with the total planting area reaching 100,000 ha (Liang et al., 2000). This system is employed under non-flooded conditions with limited irrigation and is substantially different from both traditional flooded rice cultivation and rain-fed rice cultivation. This new cultivation technique has led to improved water use efficiency, increased soil temperature, inhibition of weed growth and increased yields (Liang et al., 2000). Other mulching materials such as wheat or rice straw and even paper have subsequently been developed in rice production (Ueno and Yamanura, 1997; Wang, 2001; Fan et al., 2002).

The management of straw is another issue that is critical to sustainable agriculture in China. The burning of wheat straw is common because of the short period from wheat harvest to rice transplanting in Chinese R-W systems, particularly in the Chengdu Plain of southwest China. This leads to loss of most organic C and large losses (up to 80\%) of N (Raison, 1979), $25 \%$ of $P$ and $21 \%$ of $K$ (Ponnamperuma, 1984) as well as significant air pollution and the death of beneficial soil fauna and micro-organisms. Utilization of wheat straw is therefore an important environmental issue in southwest China. A similar situation is found in some parts of India where the time interval between rice harvesting and wheat sowing is very short (Prasad et al., 1999). One possible solution would be to use wheat straw as a soil mulch material in non-flooded rice cultivation in the $\mathrm{R}-\mathrm{W}$ rotation. Surface retention of some or all of the straw may often be the best option. Rasmussen and Collins (1991) reported that slowly decomposing crop residues on the soil surface increased organic $\mathrm{C}$ and total $\mathrm{N}$ in the top $5-15 \mathrm{~cm}$ of the soil while protecting the surface soil from erosion. Retention of straw on the surface increased soil nitrate concentrations by $46 \%, \mathrm{~N}$ uptake by $29 \%$, and yield by $37 \%$ compared to burning (Bacon, 1987; Bacon and Cooper, 1985a,b). A preliminary study by our group in 1998 also indicated a yield advantage of straw mulching in the Chengdu Plain (S.H. Lu, pers. comm.).

The evaluation of non-flooded mulching cultivation systems on growth and nutrient uptake of both rice and wheat crops is critical to the productivity and sustainability of the whole R-W systems. Our hypothesis was that both PM and wheat straw mulching (SM) cultivations alter the crop growth environment, especially root biological activity and/or nutrient availability in the rhizosphere, and then enhance or inhibit the growth and nutrient uptake of rice and ensuing wheat. The objective of the present study was to determine the effects of non-flooded mulching cultivation on grain yield, nutrient acquisition and nutrient balance in Chinese R-W systems.

\section{Materials and methods}

\subsection{Site description}

A field experiment was conducted on a Fluvaquent, calcareous grey floodplain soil at Tianhu village, Wenjiang county, Sichuan province $\left(30^{\circ} 42^{\prime} \mathrm{N}\right.$, $103^{\circ} 50^{\prime} \mathrm{E}$ and $539 \mathrm{~m}$ elevation) from 1999 to 2002. Annual mean temperature is $16.2{ }^{\circ} \mathrm{C}$ and cumulative temperatures above 0 and $10{ }^{\circ} \mathrm{C}$ are 5937 and $5107^{\circ} \mathrm{C}$, respectively. The frost-free period is 293 days and total solar radiation is $3834 \mathrm{MJ} \mathrm{m}^{-2}$ per year. The region is classified as humid sub-tropical with monsoon climate. Annual precipitation is $947 \mathrm{~mm}$ and potential evaporation $(1074 \mathrm{~mm})$ is similar to precipitation. The experimental site was located at the centre of Chengdu flood plain. The soil is a sandy loam with a bulk density of 
$1.12 \mathrm{~g} \mathrm{~cm}^{-3}$ in the top $20 \mathrm{~cm}$ and $1.45 \mathrm{~g} \mathrm{~cm}^{-3}$ at the other two depths examined (20-40 and 40-60 cm). Chemical properties in the top $20 \mathrm{~cm}$ prior to the experiment gave relatively low values (TN, $1.70 \mathrm{~g} \mathrm{~kg}^{-1}$; AP, $5.2 \mathrm{mg} \mathrm{kg}^{-1}$; EK, $37.9 \mathrm{mg} \mathrm{kg}^{-1}$; $\mathrm{OC}, 12.3 \mathrm{~g} \mathrm{~kg}^{-1}$; and $\mathrm{pH} 7.8$ ) compared with most soils of this region.

\subsection{Field experiment}

The field experiment comprised three treatments (two water regimes) during the rice growing season: traditional flooding (TF) as the control, and PM and SM as the two non-flooded mulching cultivation treatments. In the TF treatment, plots were irrigated every 3-5 days to maintain a $3 \mathrm{~cm}$ water level until 2 weeks before the rice harvest in line with traditional farming practice. No permanent water layer was maintained on the soil surface during the rice growing season in the PM and SM treatments. Limited irrigation (30-50 mm each time) was provided only from transplanting (late May) to flowering stage (early August) in all non-flooded mulching plots when soil moisture content was lower than $80 \%$ of field capacity, depending on the weather conditions. The amounts of rainfall and irrigation water in all treatments during three rice seasons (1999-2001) are listed in Table 1. All the $\mathrm{N}, \mathrm{P}$ and $\mathrm{K}$ fertilizers $\left(150 \mathrm{~kg} \mathrm{~N}^{-1}\right.$ as urea, $90 \mathrm{~kg} \mathrm{P}_{2} \mathrm{O}_{5} \mathrm{ha}^{-1}$ as calcium superphosphate and $90 \mathrm{~kg} \mathrm{~K}_{2} \mathrm{O} \mathrm{ha}^{-1}$ as potassium sulphate) were broadcast and incorporated into the top $15 \mathrm{~cm}$ of the soil in all treatments by ploughing prior to

Table 1

Amounts of irrigation and precipitation in three water regimes: TF, non-flooded PM and SM in three rice seasons from 1999 to 2001

\begin{tabular}{llrrr}
\hline Year & Water input $(\mathrm{mm})$ & TF & PM & SM \\
\hline 1999 & Precipitation & 787 & 787 & 787 \\
& Irrigation & 890 & 50 & 50 \\
& Total & 1677 & 837 & 837 \\
& & & & \\
2000 & Precipitation & 457 & 457 & 457 \\
& Irrigation & 922 & 134 & 134 \\
& Total & 1379 & 591 & 591 \\
& & & & \\
2001 & Precipitation & 638 & 638 & 638 \\
& Irrigation & 910 & 84 & 84 \\
& Total & 1548 & 722 & 722 \\
\hline
\end{tabular}

transplanting of rice. Traditional flooded and nonflooded plots were separated by a $2 \mathrm{~m}$ wide alley with plastic film inserted into the soil to $60 \mathrm{~cm}$ depth, and other plots were separated by a $0.5 \mathrm{~m}$ wide irrigation furrow and two $0.3 \mathrm{~m}$ levees. All plots were $3 \mathrm{~m} \times 8 \mathrm{~m}$ and there were three replicates of each treatment in a fully randomized design, giving a total of nine plots. The rice (Oryza sativa L.) variety used was the hybrid 'Gangyou 527', supplied by the Institute of Crop Science, Sichuan Academy of Agricultural Sciences (SAAS). The rice seedlings were transplanted at a spacing of $20 \mathrm{~cm} \times 28 \mathrm{~cm}$ with two seedlings per hill. Plastic film, $0.005 \mathrm{~mm}$ thick and $1.7 \mathrm{~m}$ wide, was used to cover the soil in the PM treatment. Wheat straw, harvested from the same field ( $\left.5250 \mathrm{~kg} \mathrm{DM} \mathrm{ha}^{-1}\right)$, was used to cover the soil uniformly (equal to about $2 \mathrm{~cm}$ height) in the SM treatment to prevent evaporation of soil water in a similar fashion to the plastic film. The average NPK concentrations were 0.48, 0.094 and $1.10 \%$, respectively. The dates of rice transplanting and harvesting were late May (24-26) and mid-September (15-18) during the 3 years from 1999 to 2001.

After the rice harvest each year, wheat (Triticum aestivum L.) was planted on the same plots with zero tillage and the removal of rice straw. Each plot was split into two equal sub-plots $(3 \mathrm{~m} \times 4 \mathrm{~m}$ each) to allow two $\mathrm{N}$ application rates (60 and $120 \mathrm{~kg} \mathrm{~N} \mathrm{ha}^{-1}$ as urea) to the wheat, representing reduced (basal application once) and normal (50\% basal application $+50 \%$ topdressing) $\mathrm{N}$ rates, respectively. The same amounts of $\mathrm{P}$ and $\mathrm{K}$ fertilizers $\left(60 \mathrm{~kg} \mathrm{P}_{2} \mathrm{O}_{5}\right.$ ha $^{-1}$ as calcium superphosphate and $60 \mathrm{~kg} \mathrm{~K}_{2} \mathrm{O} \mathrm{ha}^{-1}$ as potassium sulphate) with $60 \mathrm{~kg} \mathrm{~N} \mathrm{ha}^{-1}$ of fertilizer $\mathrm{N}$ were uniformly applied to the given hills of all plots where wheat seeds were ready to be planted prior to sowing of wheat. The subsequent topdressing of fertilizer $\mathrm{N}$ in the corresponding sub-plots receiving $120 \mathrm{~kg} \mathrm{~N} \mathrm{ha}^{-1}$ was uniformly broadcast at the booting stage of wheat (at the end of February). In early November (2-5), the wheat variety "SW3243", supplied by the Institute of Crop Science, SAAS, was sown directly into the soil at two spacings of $10 \mathrm{~cm} \times 15 \mathrm{~cm}$ and $10 \mathrm{~cm} \times 25 \mathrm{~cm}$ as bunch planting. Most residual plastic film was removed from the field before sowing of wheat in the PM treatment to avoid any negative effects on soil properties. However, the wheat straw left over from the mulching of the rice crop still remained in the field in the SM treatment. The wheat was harvested in mid-May (14-16) each year. No 
irrigation was provided during the three wheat seasons (from 1999-2000 to 2001-2002).

\subsection{Crop measurements and plant nutrient analysis}

During the first year of the experiment (1999-2000), detailed measurements were made of crop growth and dry matter partitioning, and plant NPK concentrations. During the second year (2000-2001), similar detailed measurements were carried out on rice only. During the second and third years (2000-2001 and 2001-2002), with the exception of the second rice crop, data collection was limited to final straw and grain yields and plant NPK concentrations. Shoot dry matter was determined on samples from areas of $0.3 \mathrm{~m} \times 0.6 \mathrm{~m}$ at early tillering (18-24 DAT), late tillering (40-50 DAT), booting (50-70 DAT), and physiological maturity (104112 DAT) of rice, and at tillering (47 DAT), booting (83 DAT) and physiological maturity of wheat (196 DAT). Grain and straw yields were determined by harvesting $8 \mathrm{~m}^{2}$ (rice) or $6 \mathrm{~m}^{2}$ (wheat) of each plot or sub-plot at maturity. Rice grain yields were adjusted to $140 \mathrm{~g} \mathrm{~kg}^{-1}$ moisture content while wheat grain yields were recorded on a dry matter basis. The sample plants were oven-dried for dry matter content at $60^{\circ} \mathrm{C}$ for $48 \mathrm{~h}$ and were ground and analysed for total nutrient concentrations. Nitrogen, $\mathrm{P}$, and $\mathrm{K}$ concentrations in the plant dry matter were determined after wet digestion with $\mathrm{H}_{2} \mathrm{SO}_{4}$ and $\mathrm{H}_{2} \mathrm{O}_{2}$, and $\mathrm{N}$ measured by the micro-Kjeldahl procedure, $\mathrm{P}$ by the vanadomolybdate method and $\mathrm{K}$ by flame photometry. Nutrient uptake was calculated as the product of nutrient concentration and yield of aboveground parts of the crop on a dry matter basis.

Sap nitrate concentration at the base of the wheat stems was measured using a reflectometer at the booting stage (83-90 DAS) during all three wheat growth seasons (from 1999-2000 to 2001-2002). This rapid nitrate test was described by Jemison and Fox (1988) and has been regarded as a useful tool for crop $\mathrm{N}$ nutritional diagnosis and $\mathrm{N}$ recommendations as discussed by Liu et al. (in press) and Schenk (1998).

\subsection{Soil measurement and nutrient analysis}

During the 1999 rice season, surface and subsurface $(10 \mathrm{~cm}$ depth) soil temperatures were measured by thermometer during the main growth stages of rice (15-92 DAT). Four to seven measurements from the morning to the afternoon were taken on each day of measurement. Soil moisture content at surface depths $(0-20 \mathrm{~cm})$ was determined at weekly intervals by oven drying while soil moisture content at all depths (0-20, $20-40$, and $40-60 \mathrm{~cm}$ ) was determined at the major growth stages in line with the plant sampling using the same method.

After three cycles of $\mathrm{R}-\mathrm{W}$ rotation, soil $\mathrm{pH}$, organic $\mathrm{C}(\mathrm{OC})$, total N (TN), Olsen-P (AP) and exchangeable $\mathrm{K}$ (EK) were determined for $0-10$ and $10-20 \mathrm{~cm}$ depths using standard methods as described by Sparks et al. (1996).

\subsection{Nutrient balance}

Nutrient balances of $\mathrm{N}, \mathrm{P}$ and $\mathrm{K}$ were estimated after three cycles of $\mathrm{R}-\mathrm{W}$ rotation under TF and nonflooded mulching cultivations. The nutrient balances were calculated by differences between the inputs (from fertilizer and crop straw) and outputs (from uptake by crops). The calculations were made as follows:

$$
\begin{aligned}
& \text { Apparent nutrient balance } \\
& =\text { (nutrient uptake by crops }) \\
& \quad-(\text { nutrient additions from fertilizer and crop straw })
\end{aligned}
$$

Other major pathways of NPK inputs or outputs not measured include $\mathrm{N}$ inputs from biological $\mathrm{N}$ fixation (BNF), rainfall and irrigation, gaseous $\mathrm{N}$ losses from ammonia volatilization and denitrification, leaching losses, and $\mathrm{P}$ and $\mathrm{K}$ losses from runoff and leaching. The apparent nutrient balances therefore estimate only net gains or losses of NPK.

\subsection{Statistical analysis}

Statistical analysis using SAS software (SAS Institute, 1996) on grain and straw yields, and nutrient concentration and uptake as well as soil temperature were performed by standard procedures on a randomized plot design for rice and split-plot design for wheat. Wherever treatment differences were found, significance was calculated based on results of $F$-tests and least significant differences (LSD) at the 0.05 probability level. 
Table 2

Effects of non-flooded mulching cultivation on rice grain yields at a rate of $150 \mathrm{~kg} \mathrm{~N}^{-1}$ during the period 1999-2001

\begin{tabular}{llllll}
\hline Mulching $^{\mathrm{b}}$ & $\begin{array}{l}\text { Nitrogen } \\
\left(\mathrm{kg} \mathrm{N} \mathrm{ha}^{-1}\right)\end{array}$ & 1999 & 2000 & 2001 & Mean \\
\hline $\mathrm{TF}$ & 150 & $5609 \mathrm{~b}$ & $6760 \mathrm{~b}$ & $6381 \mathrm{ab}$ & 6250 \\
$\mathrm{PM}$ & 150 & $6512 \mathrm{a}$ & $7779 \mathrm{a}$ & $6696 \mathrm{a}$ & 6996 \\
$\mathrm{SM}$ & 150 & $4799 \mathrm{c}$ & $5719 \mathrm{c}$ & $5608 \mathrm{~b}$ & 5375 \\
\hline & ${ }^{\text {a }}$ Values & with same letters & within the & same year & are not \\
significantly different. \\
b TF: traditional flooding; PM: plastic film mulching; SM: \\
wheat straw mulching.
\end{tabular}

\section{Results}

\subsection{Rice}

\subsubsection{Grain yields}

Grain yields of rice as affected by non-flooded mulching cultivation are shown in Table 2. ANOVA on grain yield revealed that during the first and second years, the main effects of non-flooded mulching were significant at the $1 \%$ level, while during the third year the treatment effects were significant only at the 5\% level (data not shown). Yields of TF and non-flooded mulching treatments ranged widely (from 4.8 to $7.8 \mathrm{tha}^{-1}$ ) over the 3-year period during which mean yield rose from 5.6 to $6.8 \mathrm{t} \mathrm{ha}^{-1}$ and then dropped to $6.2 \mathrm{tha}^{-1}$. Compared with the TF treatment, rice grain yields were significantly improved by the PM treatment but decreased by the SM treatment during the three rice growth seasons from 1999 to 2001 (Table 2). The average yield increase was $12 \%$ for the PM treatment while the average yield decline was $14 \%$ for the SM treatment compared with the TF treatment.

\subsubsection{Soil temperature}

The dynamics of surface and subsurface $(10 \mathrm{~cm}$ depth) soil temperatures as affected by non-flooded mulching cultivation systems during the 1999 rice growth period are given in Table 3. At early tillering (15-24 DAT), daily mean surface and subsurface soil temperatures were significantly higher in plots with PM but significantly lower in plots with SM than those in plots with TF, respectively. The greatest difference in soil temperature appeared during the period from 14:00 to 16:00 $\mathrm{h}$ for both soil depths (data not shown). The increase or decrease in soil temperature caused by film or straw mulching was maintained until late tillering, although the effects of mulching gradually declined with time (Table 3). Similar observations were made in the other two years (data not shown).

\subsubsection{Biomass accumulation}

Total biomass accumulation during the growth cycle varied widely between the first 2 years and was strongly influenced by non-flooded mulching cultivation (Fig. 1). In 1999, biomass accumulation (Fig. 1A) showed significant differences among TF, PM and SM treatments after tillering (up to 33 DAT). Total biomass accumulation was greater in the PM treatment but lower in the SM treatment than in the TF treatment. After booting (47 DAT), biomass accumulation in TF and PM treatments was maintained at similar rates and the differences between the two treatments became smaller. In contrast, biomass accumulation in SM treatment was consistently low compared with that in TF and PM treatments (Fig. 1A). In 2000, total biomass accumulation (Fig. 1B) was greater than in 1999 across all treatments, likely due to higher solar radiation and temperatures (data not shown). The ranking of biomass accumulation in 2000 followed the same trend as in 1999 (PM > $\mathrm{TF}>\mathrm{SM})$. The increment of biomass accumulation in TF and PM treatments was not obvious after the filling stage (81 DAT) while distinct increase in biomass accumulation was observed in SM treatment

Table 3

Dynamics of daily mean temperature $\left({ }^{\circ} \mathrm{C}\right)$ at soil surface and subsurface $(10 \mathrm{~cm}$ depth) as affected by non-flooded mulching cultivation systems (1999) ${ }^{\mathrm{a}}$

\begin{tabular}{|c|c|c|c|c|}
\hline Mulching $^{\mathrm{b}}$ & $\begin{array}{l}\text { Early tillering } \\
\left(15-24 \mathrm{DAT}^{\mathrm{c}}\right)\end{array}$ & $\begin{array}{l}\text { Mid-tillering } \\
\text { (27-36 DAT) }\end{array}$ & $\begin{array}{l}\text { Late tillering } \\
\text { (39-50 DAT) }\end{array}$ & Mean \\
\hline \multicolumn{5}{|l|}{ Soil surface } \\
\hline $\mathrm{TF}$ & $31.3 \mathrm{~b}$ & $30.8 \mathrm{a}$ & $28.7 \mathrm{a}$ & 30.2 \\
\hline PM & $37.5 \mathrm{a}$ & $32.6 \mathrm{a}$ & $30.5 \mathrm{a}$ & 33.5 \\
\hline SM & $27.3 \mathrm{c}$ & $27.4 \mathrm{~b}$ & $28.4 \mathrm{a}$ & 27.7 \\
\hline \multicolumn{5}{|c|}{ Soil subsurface } \\
\hline TF & $27.1 \mathrm{~b}$ & $24.9 \mathrm{ab}$ & $26.2 \mathrm{a}$ & 26.0 \\
\hline PM & $29.0 \mathrm{a}$ & $25.7 \mathrm{a}$ & $26.4 \mathrm{a}$ & 27.1 \\
\hline SM & $24.6 \mathrm{c}$ & $23.9 \mathrm{~b}$ & $25.2 \mathrm{a}$ & 24.6 \\
\hline
\end{tabular}

${ }^{a}$ Values with same letters within the same column are not significantly different.

${ }^{\mathrm{b}}$ TF: traditional flooding; PM: plastic film mulching; SM: wheat straw mulching.

${ }^{\mathrm{c}}$ Days after transplanting. 

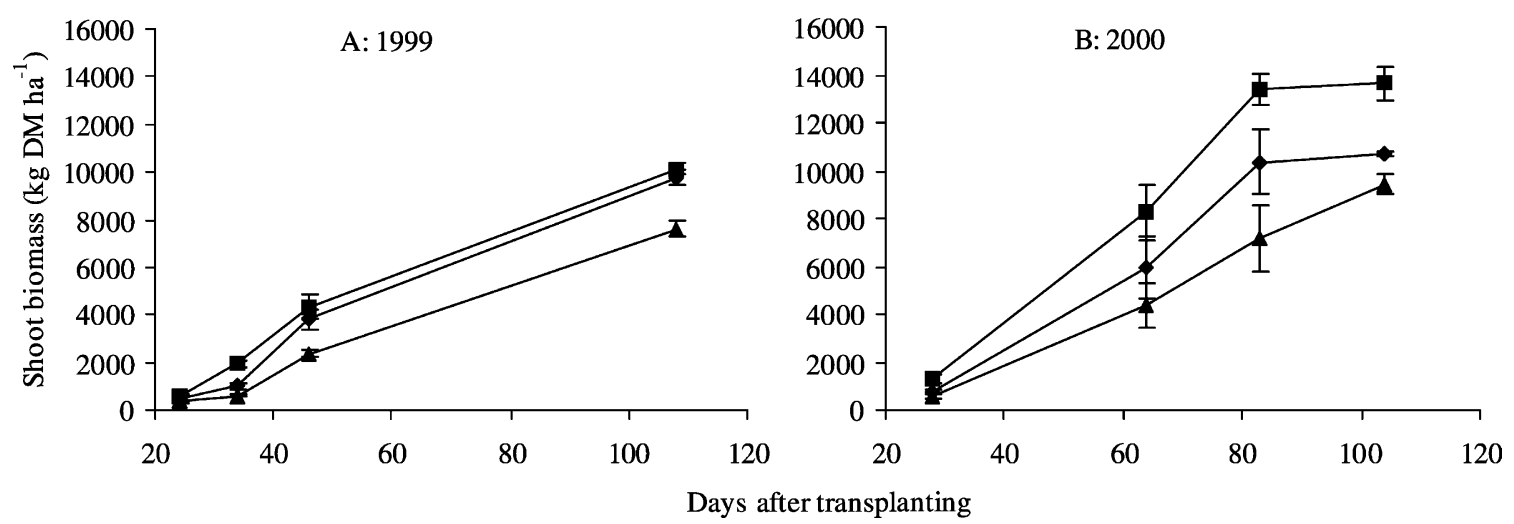

Fig. 1. Dynamics of rice shoot biomass as affected by three water regimes of TF ( $\bullet$ ), PM ( $\boldsymbol{\square})$ and SM (A) in 1999 (A) and 2000 (B). Bars represent \pm S.E.M.

from filling to maturity stage, indicating a compensatory growth effect in the latter treatment. The 2-year results indicate that SM may inhibit the growth of rice while PM can improve the growth of rice, and this is consistent with the changes in soil temperature as affected by non-flooded mulching cultivation.

\subsubsection{Nutrient concentration and uptake}

Nutrient concentrations in grain and straw of rice as affected by non-flooded mulching are presented in Table 4. Nitrogen concentrations in grain and straw were not significantly influenced by non-flooded mulching with the exceptions of 1999 rice straw and 2000 rice grain. The mean $\mathrm{N}$ concentrations in grain (1.13-1.26\%) and straw (0.65-0.71\%) followed the same trend of PM and SM $>$ TF (Table 4). The prolonged growth period in SM and PM treatments could partly explain the relatively high $\mathrm{N}$ concentration in grain or straw compared with the TF treatment. However, $\mathrm{N}$ concentrations were significantly lower in SM than in TF and PM only at tillering in the first and second years (data not shown), suggesting that the effect of SM on shoot $\mathrm{N}$ nutrition occurred mainly during the early growth of rice. Phosphorus

Table 4

Nutrient concentration (\%) in rice grain and straw as affected by three water regimes of TF, PM and SM during 3 years $^{\mathrm{a}}$

\begin{tabular}{|c|c|c|c|c|c|c|c|c|c|}
\hline \multirow[t]{2}{*}{ Mulching ${ }^{\mathrm{b}}$} & \multirow{2}{*}{$\begin{array}{l}\text { Nitrogen } \\
\left(\mathrm{kg} \mathrm{N} \mathrm{ha}^{-1}\right)\end{array}$} & \multicolumn{2}{|l|}{1999} & \multicolumn{2}{|l|}{2000} & \multicolumn{2}{|l|}{2001} & \multicolumn{2}{|l|}{ Mean } \\
\hline & & Grain & Straw & Grain & Straw & Grain & Straw & Grain & Straw \\
\hline \multicolumn{10}{|l|}{ Nitrogen } \\
\hline $\mathrm{TF}$ & 150 & $1.24 \mathrm{a}$ & $0.61 \mathrm{~b}$ & $0.98 \mathrm{~b}$ & $0.59 \mathrm{a}$ & $1.17 \mathrm{a}$ & $0.75 \mathrm{a}$ & 1.13 & 0.65 \\
\hline PM & 150 & $1.35 \mathrm{a}$ & $0.65 \mathrm{ab}$ & $1.15 \mathrm{a}$ & $0.65 \mathrm{a}$ & $1.28 \mathrm{a}$ & $0.79 \mathrm{a}$ & 1.26 & 0.70 \\
\hline SM & 150 & $1.19 \mathrm{a}$ & $0.77 \mathrm{a}$ & $1.07 \mathrm{ab}$ & $0.59 \mathrm{a}$ & $1.27 \mathrm{a}$ & $0.76 \mathrm{a}$ & 1.18 & 0.71 \\
\hline \multicolumn{10}{|l|}{ Phosphorus } \\
\hline TF & 150 & $0.30 \mathrm{a}$ & $0.05 \mathrm{a}$ & $0.24 \mathrm{a}$ & $0.06 \mathrm{a}$ & $0.32 \mathrm{a}$ & $0.10 \mathrm{a}$ & 0.29 & 0.07 \\
\hline PM & 150 & $0.31 \mathrm{a}$ & $0.09 \mathrm{a}$ & $0.26 \mathrm{a}$ & $0.07 \mathrm{a}$ & $0.32 \mathrm{a}$ & $0.10 \mathrm{a}$ & 0.30 & 0.09 \\
\hline SM & 150 & $0.30 \mathrm{a}$ & $0.08 \mathrm{a}$ & $0.24 \mathrm{a}$ & $0.07 \mathrm{a}$ & $0.34 \mathrm{a}$ & $0.09 \mathrm{a}$ & 0.29 & 0.08 \\
\hline \multicolumn{10}{|l|}{ Potassium } \\
\hline $\mathrm{TF}$ & 150 & $0.21 \mathrm{a}$ & $2.26 \mathrm{~b}$ & $0.25 \mathrm{a}$ & $2.43 \mathrm{~b}$ & $0.18 \mathrm{~b}$ & $2.17 \mathrm{a}$ & 0.21 & 2.28 \\
\hline PM & 150 & $0.26 \mathrm{a}$ & $2.62 \mathrm{ab}$ & $0.27 \mathrm{a}$ & $2.51 \mathrm{ab}$ & $0.21 \mathrm{~b}$ & $2.05 \mathrm{a}$ & 0.25 & 2.37 \\
\hline SM & 150 & $0.27 \mathrm{a}$ & $2.75 \mathrm{a}$ & $0.26 \mathrm{a}$ & $2.54 \mathrm{a}$ & $0.29 \mathrm{a}$ & $2.34 \mathrm{a}$ & 0.27 & 2.53 \\
\hline
\end{tabular}

${ }^{a}$ Values with same letters within the same column are not significantly different.

${ }^{\mathrm{b}}$ TF: traditional flooding; PM: plastic film mulching; SM: wheat straw mulching. 
Table 5

Nutrient uptake $\left(\mathrm{kg} \mathrm{ha}^{-1}\right)$ by rice as affected by non-flooded mulching cultivation from 1999 to $2001^{\mathrm{a}}$

\begin{tabular}{lllrrr}
\hline Mulching $^{\mathrm{b}}$ & $\begin{array}{l}\text { Nitrogen } \\
\left(\mathrm{kg} \mathrm{N} \mathrm{ha}^{-1}\right)\end{array}$ & 1999 & 2000 & 2001 & Mean \\
\hline $\begin{array}{l}\text { Nitrogen } \\
\text { TF }\end{array}$ & 150 & $89 \mathrm{ab}$ & $98 \mathrm{~b}$ & $109 \mathrm{a}$ & 99 \\
PM & 150 & $105 \mathrm{a}$ & $122 \mathrm{a}$ & $124 \mathrm{a}$ & 117 \\
SM & 150 & $76 \mathrm{~b}$ & $81 \mathrm{c}$ & $102 \mathrm{a}$ & 86 \\
Phosphorus & & & & & \\
TF & 150 & $19 \mathrm{ab}$ & $22 \mathrm{a}$ & $24 \mathrm{a}$ & 22 \\
PM & 150 & $22 \mathrm{a}$ & $24 \mathrm{a}$ & $25 \mathrm{a}$ & 24 \\
SM & 150 & $16 \mathrm{~b}$ & $18 \mathrm{~b}$ & $21 \mathrm{a}$ & 18 \\
Potassium & & & & & \\
TF & 150 & $121 \mathrm{ab}$ & $133 \mathrm{~b}$ & $138 \mathrm{a}$ & 131 \\
PM & 150 & $133 \mathrm{a}$ & $198 \mathrm{a}$ & $139 \mathrm{a}$ & 156 \\
SM & 150 & $108 \mathrm{~b}$ & $127 \mathrm{~b}$ & $135 \mathrm{a}$ & 123 \\
\hline
\end{tabular}

${ }^{a}$ Values with same letters within the same column are not significantly different.

${ }^{\mathrm{b}}$ TF: traditional flooding; PM: plastic film mulching; SM: wheat straw mulching.

concentrations in grain and straw were not significantly influenced by non-flooded mulching across years (Table 4). The mean P concentrations in grain and straw were $0.29-0.30$ and $0.07-0.09 \%$, respectively. Potassium concentrations in grain and straw, however, were significantly influenced by non-flooded mulching only in the third year (grain) and the first and second years (straw). Mean K concentrations were $0.21-0.27 \%$ for grain and $2.28-2.53 \%$ for straw and followed the sequence $\mathrm{SM}>\mathrm{PM}>\mathrm{TF}$ (Table 4). The distribution of nutrient concentrations in grain and straw showed the integrated effects of non-flooded mulching cultivation on rice growth and NPK availability in soils.

As with grain yield, nutrient uptake by rice was promoted by PM treatment but limited by the SM treatment compared with TF across years (Table 5). Nitrogen uptake by rice showed a continuous increase from 1999 to 2001 for all treatments, which was consistent with the $\mathrm{N}$ concentrations in grain and straw (Table 4). Mean N uptake was 99, 117 and $86 \mathrm{~kg} \mathrm{~N} \mathrm{ha}^{-1}$ for TF, PM and SM, respectively. Phosphorus and potassium uptake as affected by nonflooded mulching cultivation followed a trend similar to that of $\mathrm{N}$ (Table 5). Mean $\mathrm{P}$ uptake by rice ranged from 18 to $24 \mathrm{~kg} \mathrm{P}^{-1}$ while mean $\mathrm{K}$ uptake was
123-156 kg K ha ${ }^{-1}$ for three treatments. In contrast to the first and second years, no significant effects of nonflooded mulching were found on N, P or K uptake in the third year (Table 5).

\subsection{Wheat}

\subsubsection{Grain yields}

Grain yields of wheat as affected by non-flooded mulching to preceding rice and split $\mathrm{N}$ rate are presented in Table 6. Compared with rice, individual treatments resulted in a less range of wheat yields from 4.3 to $6.2 \mathrm{tha}^{-1}$ over 3 years (Table 6). The mean yield of wheat was highest in the first year $\left(5.5 \mathrm{tha}^{-1}\right)$, then fell progressively to 5.2 and $4.7 \mathrm{tha}^{-1}$ in the second and third years, respectively. In contrast to rice, SM treatment led to significantly higher grain yields of wheat at reduced $\mathrm{N}$ rate $\left(60 \mathrm{~kg} \mathrm{~N} \mathrm{ha}^{-1}\right)$ during the 3 years compared with $\mathrm{TF}$ and PM treatments. There were no significant differences between wheat yields in PM and TF treatments in spite of $\mathrm{N}$ rates used. A reduction in fertilizer rate from 120 to $60 \mathrm{~kg} \mathrm{~N} \mathrm{ha}^{-1}$ caused a significant yield decline in PM and TF treatments during the first and second years (Table 6). In contrast, in the SM treatment, a higher yield was observed in sub-plots receiving $60 \mathrm{~kg} \mathrm{~N}^{-1}$ than in those receiving $120 \mathrm{~kg} \mathrm{~N} \mathrm{ha}^{-1}$ (Table 6). These results suggest that soil $\mathrm{N}$ supply in the wheat season is increased by SM treatment to preceding rice.

Table 6

Residual effects of non-flooded mulching cultivation to preceding rice on wheat grain yield $\left(\mathrm{kg} \mathrm{ha}^{-1}\right)$ at two $\mathrm{N}$ rates

\begin{tabular}{lccccc}
\hline Mulching $^{\mathrm{a}}$ & $\begin{array}{l}\text { Nitrogen } \\
\left(\mathrm{kg} \mathrm{N} \mathrm{ha}^{-1}\right)\end{array}$ & 1999 & 2000 & 2001 & Mean \\
\hline TF & 60 & 4545 & 4838 & 4506 & 4630 \\
& 120 & 5610 & 5263 & 4509 & 5127 \\
PM & 60 & 4710 & 4310 & 4387 & 4469 \\
& 120 & 5888 & 5433 & 4769 & 5363 \\
SM & 60 & 6240 & 5906 & 5064 & 5737 \\
& 120 & 6038 & 5473 & 4918 & 5476 \\
& & 591 & 187 & n.s. & \\
LSD $_{0.05}(\mathrm{M})$ & & 482 & 153 & n.s. & \\
LSD $_{0.05}(\mathrm{~N})$ & & & & &
\end{tabular}

\footnotetext{
${ }^{a}$ TF: traditional flooding; PM: plastic film mulching; SM: wheat straw mulching.

${ }^{\mathrm{b}}$ Not significant.
} 

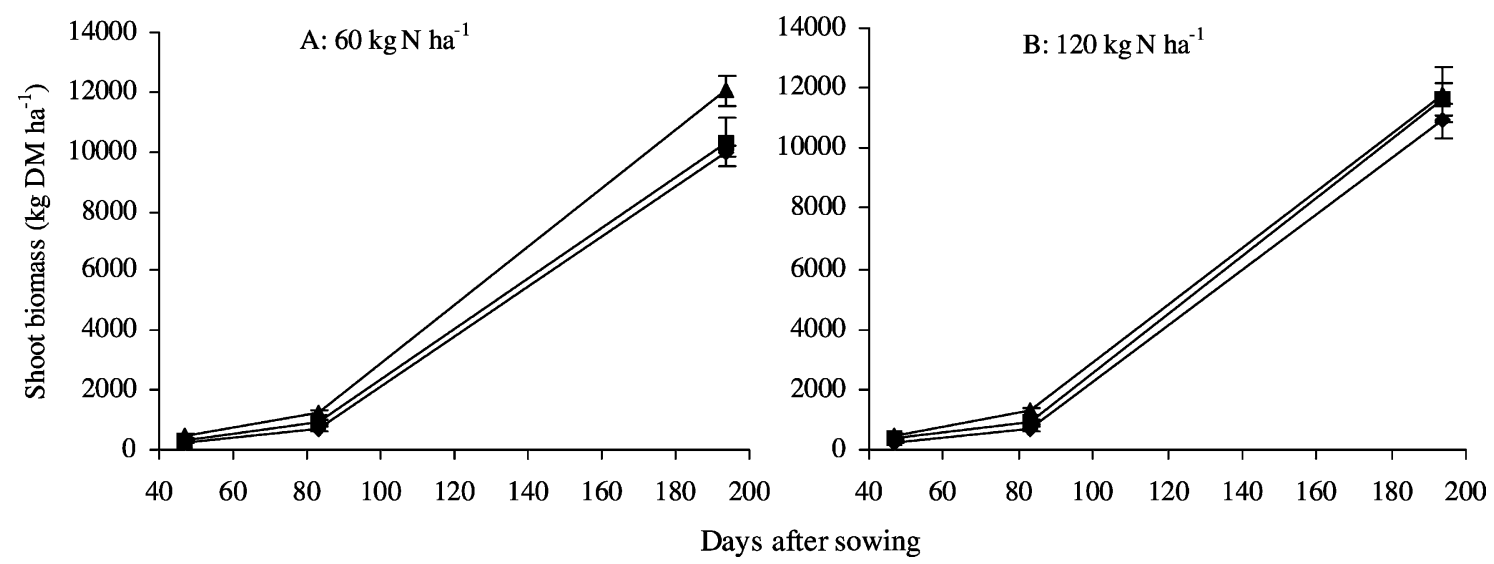

Fig. 2. Dynamics of shoot biomass of wheat (1999-2000) as affected by three water regimes of TF ( $\bullet$ ), PM ( $\mathbf{\square})$ and SM ( $\mathbf{\Delta})$ in rice and two $\mathrm{N}$ rates $\left(60\right.$ and $\left.120 \mathrm{~kg} \mathrm{~N} \mathrm{ha}^{-1}\right)$ in wheat. Bars represent \pm S.E.M.

\subsubsection{Biomass accumulation}

Total biomass accumulation of wheat (1999-2000) as influenced by non-flooded mulching to previous rice and $\mathrm{N}$ rate is presented in Fig. 2. At tillering (47 DAS), biomass accumulation was relatively small $\left(0.3-0.5 \mathrm{tha}^{-1}\right)$ and no significant differences were observed among all treatments across two $\mathrm{N}$ rates. At booting (83 DAS), biomass accumulation in SM treatment $\left(1.3 \mathrm{t} \mathrm{ha}^{-1}\right)$ was significantly greater than that in $\mathrm{TF}$ and PM treatments $\left(0.7-0.9 \mathrm{t} \mathrm{ha}^{-1}\right)$. Total biomass accumulation at maturity in the SM treatment reached $12.0 \mathrm{tha}^{-1}$ while the corresponding biomass accumulations were only $10.0-10.3 \mathrm{t} \mathrm{ha}^{-1}$ in other two treatments at a rate of $60 \mathrm{~kg} \mathrm{~N} \mathrm{ha}^{-1}$ (Fig. 2A). In contrast, the differences in biomass accumulation among SM, $\mathrm{TF}$, and PM treatments were much smaller at a rate of $120 \mathrm{~kg} \mathrm{~N} \mathrm{ha}^{-1}$ (Fig. 2B), indicating that the growth promoting effects on wheat biomass accumulation by SM to preceding rice was significant only at lower $\mathrm{N}$ input levels.

\subsubsection{Nutrient concentration and uptake}

Nutrient concentrations in grain and straw of wheat as affected by non-flooded mulching to preceding rice and $\mathrm{N}$ rate are presented in Table 7. At reduced $\mathrm{N}$ rate $\left(60 \mathrm{~kg} \mathrm{~N} \mathrm{ha}^{-1}\right), \mathrm{N}$ concentrations in straw were significantly different among TF, PM and SM treatments while no significant differences in grain $\mathrm{N}$ were observed among those treatments. Nitrogen concentrations in both grain and straw were increased by
$120 \mathrm{~kg} \mathrm{~N} \mathrm{ha}^{-1}$ compared with $60 \mathrm{~kg} \mathrm{~N} \mathrm{ha}^{-1}$ across non-flooded mulching treatments and over years. However, the mean increment of $\mathrm{N}$ concentration at normal $\mathrm{N}$ rate $\left(120 \mathrm{~kg} \mathrm{~N} \mathrm{ha}^{-1}\right)$ was greater in grain for $\mathrm{TF}$ and PM treatments but greater in straw for SM treatment than at the reduced $\mathrm{N}$ rate, indicating the over-fertilization to wheat at an $\mathrm{N}$ rate of $120 \mathrm{~kg} \mathrm{~N}$ $\mathrm{ha}^{-1}$ for SM treatment. $\mathrm{P}$ concentrations in grain and straw were not significantly affected by non-flooded mulching treatment and $\mathrm{N}$ rate over years (Table 7). The mean $\mathrm{P}$ concentrations showed narrow variations in grain $(0.37-0.42 \%)$ and in straw $(0.06-0.08 \%)$. K concentrations in straw were only significantly affected by non-flooded mulching to preceding rice in the first year and by the $\mathrm{N}$ rate in the third year while $\mathrm{K}$ concentrations in grain were not during 3 years (Table 7). SM to preceding rice led to the highest mean K concentrations (1.18-1.30\%) in straw, followed by PM (1.10-1.13\%) and then TF (0.99-1.05\%).

Nutrient uptake by wheat as affected by nonflooded mulching to preceding rice and $\mathrm{N}$ rate is presented in Table 8 . Nitrogen uptake by wheat was significantly influenced by non-flooded mulching treatments at a rate of $60 \mathrm{~kg} \mathrm{~N} \mathrm{ha}^{-1}$, following the sequence $\mathrm{SM}>\mathrm{TF}$ and PM over 3 years. However, no significant differences in $\mathrm{N}$ uptake among TF, PM and SM treatments were observed at a rate of $120 \mathrm{~kg} \mathrm{~N} \mathrm{ha}^{-1}$. These $\mathrm{N}$ concentration and uptake data suggest that $\mathrm{SM}$ to preceding rice could meet the $\mathrm{N}$ requirement of wheat at a reduced $\mathrm{N}$ rate. 
Table 7

Nutrient concentration (\%) in grain and straw of wheat as affected by three water regimes of TF, PM and SM in rice and two N rates in wheat during 3 years

\begin{tabular}{|c|c|c|c|c|c|c|c|c|c|}
\hline \multirow[t]{2}{*}{ Mulching ${ }^{\mathrm{a}}$} & \multirow{2}{*}{$\begin{array}{l}\text { Nitrogen } \\
\left(\mathrm{kg} \mathrm{N} \mathrm{ha}^{-1}\right)\end{array}$} & \multicolumn{2}{|c|}{$1999 / 2000$} & \multicolumn{2}{|c|}{$2000 / 2001$} & \multicolumn{2}{|c|}{$2001 / 2002$} & \multicolumn{2}{|l|}{ Mean } \\
\hline & & Grain & Straw & Grain & Straw & Grain & Straw & Grain & Straw \\
\hline \multicolumn{10}{|l|}{ Nitrogen } \\
\hline \multirow[t]{2}{*}{$\mathrm{TF}$} & 60 & 1.48 & 0.28 & 1.46 & 0.36 & 1.45 & 0.39 & 1.46 & 0.34 \\
\hline & 120 & 1.59 & 0.36 & 1.56 & 0.44 & 1.63 & 0.46 & 1.59 & 0.42 \\
\hline \multirow[t]{2}{*}{$\mathrm{PM}$} & 60 & 1.48 & 0.30 & 1.49 & 0.35 & 1.51 & 0.47 & 1.49 & 0.37 \\
\hline & 120 & 1.79 & 0.38 & 1.60 & 0.41 & 1.57 & 0.56 & 1.65 & 0.45 \\
\hline \multirow[t]{2}{*}{ SM } & 60 & 1.45 & 0.38 & 1.59 & 0.40 & 1.47 & 0.45 & 1.50 & 0.41 \\
\hline & 120 & 1.50 & 0.56 & 1.61 & 0.45 & 1.58 & 0.58 & 1.56 & 0.53 \\
\hline \multicolumn{2}{|l|}{$\operatorname{LSD}_{0.05}(\mathrm{M})$} & n.s. & 0.09 & n.s. ${ }^{b}$ & n.s. & n.s. & n.s. & & \\
\hline $\mathrm{LSD}_{0.05}(\mathrm{~N})$ & & n.s. & 0.07 & n.s. & n.s. & n.s. & 0.11 & & \\
\hline \multicolumn{10}{|l|}{ Phosphorus } \\
\hline \multirow[t]{2}{*}{$\mathrm{TF}$} & 60 & 0.43 & 0.10 & 0.45 & 0.07 & 0.31 & 0.07 & 0.40 & 0.08 \\
\hline & 120 & 0.45 & 0.09 & 0.48 & 0.07 & 0.32 & 0.06 & 0.42 & 0.07 \\
\hline \multirow[t]{2}{*}{$\mathrm{PM}$} & 60 & 0.42 & 0.08 & 0.44 & 0.05 & 0.31 & 0.06 & 0.39 & 0.06 \\
\hline & 120 & 0.41 & 0.10 & 0.45 & 0.05 & 0.31 & 0.06 & 0.39 & 0.07 \\
\hline \multirow[t]{2}{*}{$\mathrm{SM}$} & 60 & 0.38 & 0.07 & 0.42 & 0.05 & 0.30 & 0.05 & 0.37 & 0.06 \\
\hline & 120 & 0.41 & 0.10 & 0.43 & 0.05 & 0.29 & 0.06 & 0.38 & 0.07 \\
\hline \multicolumn{2}{|l|}{$\mathrm{LSD}_{0.05}(\mathrm{M})$} & n.s. & n.s. & n.s. & n.s. & n.s. & n.s. & & \\
\hline \multicolumn{2}{|l|}{$\operatorname{LSD}_{0.05}(\mathrm{~N})$} & n.s. & n.s. & n.s. & n.s. & n.s. & n.s. & & \\
\hline \multicolumn{10}{|l|}{ Potassium } \\
\hline \multirow[t]{2}{*}{$\mathrm{TF}$} & 60 & 0.56 & 1.00 & 0.46 & 0.84 & 0.47 & 1.14 & 0.50 & 0.99 \\
\hline & 120 & 0.56 & 1.04 & 0.48 & 0.89 & 0.52 & 1.23 & 0.52 & 1.05 \\
\hline \multirow[t]{2}{*}{$\mathrm{PM}$} & 60 & 0.52 & 1.25 & 0.45 & 0.95 & 0.51 & 1.11 & 0.49 & 1.10 \\
\hline & 120 & 0.59 & 1.14 & 0.47 & 0.92 & 0.50 & 1.33 & 0.52 & 1.13 \\
\hline \multirow[t]{2}{*}{$\mathrm{SM}$} & 60 & 0.50 & 1.33 & 0.48 & 1.01 & 0.46 & 1.21 & 0.48 & 1.18 \\
\hline & 120 & 0.55 & 1.49 & 0.51 & 1.04 & 0.46 & 1.36 & 0.51 & 1.30 \\
\hline \multirow{2}{*}{\multicolumn{2}{|c|}{$\begin{array}{l}\operatorname{LSD}_{0.05}(\mathrm{M}) \\
\mathrm{LSD}_{0.05}(\mathrm{~N})\end{array}$}} & n.s. & 0.16 & n.s. & n.s. & n.s. & n.s. & & \\
\hline & & n.s. & n.s. & n.s. & n.s. & n.s. & 0.15 & & \\
\hline
\end{tabular}

a TF: traditional flooding; PM: plastic film mulching; SM: wheat straw mulching.

${ }^{\mathrm{b}}$ Not significant.

$\mathrm{P}$ uptake by wheat was not significantly influenced by non-flooded mulching in most cases in spite of the decline in total uptake in the third year (Table 8). Mean $\mathrm{P}$ uptake by wheat range from 22 to $27 \mathrm{~kg} \mathrm{P}$ ha $^{-1}$ across $\mathrm{N}$ rates. $\mathrm{K}$ uptake by wheat was significantly influenced by non-flooded mulching in the first and second years but not influenced by $\mathrm{N}$ rate across years (Table 8). The trend in $\mathrm{K}$ uptake was similar to that of $\mathrm{N}$ uptake, ranked by the sequence $\mathrm{SM}>\mathrm{PM} \geq \mathrm{TF}$ at both $\mathrm{N}$ rates.

\section{3. $R-W$ cropping systems}

\subsubsection{System productivity}

Total annual and mean system productivity for RW cropping systems as affected by non-flooded mulching and $\mathrm{N}$ rate are listed in Table 9. System productivity for individual treatments and years showed a relatively narrow range (from 10.1 to $12.4 \mathrm{tha}^{-1}$ ), while for the mean of 3 years across treatments it ranged from 10.9 to $12.4 \mathrm{tha}^{-1}$. In 
Table 8

Nutrient uptake $\left(\mathrm{kg} \mathrm{ha}^{-1}\right)$ by wheat following rice as affected by non-flooded mulching to preceding rice and $\mathrm{N}$ rate from 1999 2000 to $2001-2002$

\begin{tabular}{|c|c|c|c|c|c|}
\hline Mulching $^{a}$ & $\begin{array}{l}\text { Nitrogen } \\
\left(\mathrm{kg} \mathrm{N} \mathrm{ha}^{-1}\right)\end{array}$ & 1999-2000 & $2000-2001$ & $2001-2002$ & Mean \\
\hline \multicolumn{6}{|l|}{ Nitrogen } \\
\hline \multirow[t]{2}{*}{$\mathrm{TF}$} & 60 & 92 & 90 & 82 & 88 \\
\hline & 120 & 108 & 107 & 93 & 103 \\
\hline \multirow[t]{2}{*}{ PM } & 60 & 87 & 80 & 91 & 86 \\
\hline & 120 & 129 & 112 & 105 & 115 \\
\hline \multirow[t]{2}{*}{ SM } & 60 & 112 & 119 & 92 & 108 \\
\hline & 120 & 121 & 111 & 104 & 112 \\
\hline $\mathrm{LSD}_{0.05}(\mathrm{M})$ & & 10.1 & 7.0 & n.s. ${ }^{b}$ & \\
\hline $\mathrm{LSD}_{0.05}(\mathrm{~N})$ & & 8.3 & 5.8 & n.s. & \\
\hline \multicolumn{6}{|l|}{ Phosphorus } \\
\hline \multirow[t]{2}{*}{$\mathrm{TF}$} & 60 & 25 & 27 & 21 & 24 \\
\hline & 120 & 30 & 29 & 21 & 27 \\
\hline \multirow[t]{2}{*}{ PM } & 60 & 24 & 22 & 21 & 22 \\
\hline & 120 & 31 & 28 & 23 & 27 \\
\hline \multirow[t]{2}{*}{ SM } & 60 & 28 & 29 & 23 & 27 \\
\hline & 120 & 30 & 27 & 22 & 26 \\
\hline $\mathrm{LSD}_{0.05}(\mathrm{M})$ & & n.s. & 2.5 & n.s. & \\
\hline $\operatorname{LSD}_{0.05}(\mathrm{~N})$ & & 3.2 & n.s. & n.s. & \\
\hline \multicolumn{6}{|l|}{ Potassium } \\
\hline \multirow[t]{2}{*}{$\mathrm{TF}$} & 60 & 80 & 70 & 70 & 77 \\
\hline & 120 & 87 & 75 & 77 & 80 \\
\hline \multirow[t]{2}{*}{ PM } & 60 & 94 & 62 & 80 & 79 \\
\hline & 120 & 99 & 80 & 93 & 91 \\
\hline \multirow[t]{2}{*}{ SM } & 60 & 109 & 97 & 84 & 97 \\
\hline & 120 & 120 & 89 & 90 & 100 \\
\hline $\mathrm{LSD}_{0.05}(\mathrm{M})$ & & 14.3 & 13.7 & n.s. & \\
\hline $\operatorname{LSD}_{0.05}(\mathrm{~N})$ & & n.s. & n.s. & n.s. & \\
\hline
\end{tabular}

a TF: traditional flooding; PM: plastic film mulching; SM: wheat straw mulching.

${ }^{\mathrm{b}}$ Not significant.

general, system productivity followed the same sequence of $\mathrm{PM}>\mathrm{TF}>\mathrm{SM}$ in spite of $\mathrm{N}$ inputs to the whole cropping system. Across years, system productivity was greater under normal $\mathrm{N}$ input $\left(150-120 \mathrm{~kg} \mathrm{~N} \mathrm{ha}^{-1}\right)$ than under reduced $\mathrm{N}$ input $\left(150-60 \mathrm{~kg} \mathrm{~N} \mathrm{ha}^{-1}\right.$ ) for TF and PM treatments (Table 9). However, the normal $\mathrm{N}$ input led to a slight decline in system productivity in the SM treatment compared with the reduced $\mathrm{N}$ input, suggesting that a reduction of $60 \mathrm{~kg} \mathrm{~N} \mathrm{ha}^{-1}$ may be sufficient for wheat following rice under SM conditions.
Table 9

Annual and mean total system productivity ${ }^{\mathrm{a}}\left(\mathrm{kg} \mathrm{ha}^{-1}\right)$ for R-W systems under three water regimes in rice and two $\mathrm{N}$ rates in wheat

\begin{tabular}{llllll}
\hline Mulching $^{\mathrm{b}}$ & $\begin{array}{l}\text { Nitrogen } \\
\left(\mathrm{kg} \mathrm{N} \mathrm{ha}^{-1}\right)^{\mathrm{c}}\end{array}$ & Year 1 & Year 2 & Year 3 & Mean \\
\hline TF & $150-60$ & 10154 & 11598 & 10887 & 10880 \\
& $150-120$ & 11219 & 12023 & 10890 & 11377 \\
PM & $150-60$ & 11222 & 12089 & 11083 & 11465 \\
& $150-120$ & 12400 & 13212 & 11465 & 12359 \\
SM & $150-60$ & 11039 & 11625 & 10672 & 11112 \\
& $150-120$ & 10837 & 11192 & 10526 & 10851 \\
Mean & & 11145 & 11956 & 10920 & 11340 \\
\hline
\end{tabular}

a Total system productivity refers to combined yields of rice and wheat, respectively.

${ }^{\mathrm{b}} \mathrm{TF}$ : traditional flooding; PM: plastic film mulching; SM: wheat straw mulching.

${ }^{\mathrm{c}}$ The first value is for rice and the second is for wheat.

\subsubsection{Apparent nutrient balance}

Total nutrient balance in the three cycles of $\mathrm{R}-\mathrm{W}$ cropping system is presented in Table 10. Apparent $\mathrm{N}$ balance was largely influenced by $\mathrm{TN}$ inputs to the R$\mathrm{W}$ systems. Reduced $\mathrm{N}$ rate $\left(150-60 \mathrm{~kg} \mathrm{~N} \mathrm{ha}^{-1}\right.$ ) caused much lower net $\mathrm{N}$ balance compared with higher $\mathrm{N}$ rate $\left(150-120 \mathrm{~kg} \mathrm{~N} \mathrm{ha}^{-1}\right)$. At the reduced $\mathrm{N}$ rate, TN inputs were $630 \mathrm{~kg} \mathrm{~N}^{-1}$ in TF and PM treatments while they were $705 \mathrm{~kg} \mathrm{Nha}^{-1}$ in SM treatment due to the $\mathrm{N}$ addition from wheat straw $\left(75 \mathrm{~kg} \mathrm{~N} \mathrm{ha}^{-1}\right.$ ) as mulch material. Total $\mathrm{N}$ outputs (uptake by crops) were comparable $(560-609 \mathrm{~kg}$ $\mathrm{Nha}^{-1}$ ) with the TN inputs in TF, PM and SM treatments. Hence, net $\mathrm{N}$ balances were relatively low (21-123 kg N ha ${ }^{-1}$ ). At the normal $\mathrm{N}$ rate, however, the higher $\mathrm{TN}$ inputs than at the reduced $\mathrm{N}$ rate in the three treatments did not produce correspondingly higher $\mathrm{N}$ outputs (only $13-88 \mathrm{~kg} \mathrm{~N} \mathrm{ha}^{-1}$ ). Thus the net $\mathrm{N}$ balances (113-310 $\mathrm{kg} \mathrm{N}^{-1}$ ) were much greater at normal $\mathrm{N}$ rate than at reduced $\mathrm{N}$ rate. Among the three treatments, PM led to the lowest net $\mathrm{N}$ balance due to the highest $\mathrm{N}$ outputs whereas SM led to the highest net $\mathrm{N}$ balance due to the highest $\mathrm{N}$ inputs and the lowest $\mathrm{N}$ outputs. Apparent $\mathrm{P}$ and $\mathrm{K}$ balances were not significantly affected by the $\mathrm{N}$ input levels during the 3 years of $\mathrm{R}-\mathrm{W}$ rotation (Table 10). Net $\mathrm{P}$ balance was positive due to the much higher $\mathrm{P}$ inputs than $\mathrm{P}$ outputs in spite of $\mathrm{N}$ rate. In contrast, net $\mathrm{K}$ balance was always negative because the total $\mathrm{K}$ inputs were 
Table 10

Net nutrient balances in three cycles of R-W systems as affected by non-flooded mulching cultivation and $\mathrm{N}$ rate

\begin{tabular}{|c|c|c|c|c|c|}
\hline Mulching $^{\mathrm{a}}$ & $\begin{array}{l}\text { Nitrogen } \\
\left(\mathrm{kg} \mathrm{N} \mathrm{ha}^{-1}\right)^{\mathrm{b}}\end{array}$ & $\begin{array}{l}\text { Fertilizer } \\
\text { input (1) }\end{array}$ & $\begin{array}{l}\text { Addition from } \\
\text { straw (2) }\end{array}$ & $\begin{array}{l}\text { Uptake by } \\
\text { crops (3) }\end{array}$ & $\begin{array}{l}\text { Net balance } \\
(=1+2-3)\end{array}$ \\
\hline \multicolumn{6}{|c|}{ Nitrogen $\left(\mathrm{kg} \mathrm{N} \mathrm{ha}^{-1}\right)$} \\
\hline \multirow[t]{2}{*}{$\mathrm{TF}$} & $150-60$ & 630 & 0 & 560 & 70 \\
\hline & $150-120$ & 810 & 0 & 604 & 206 \\
\hline \multirow[t]{2}{*}{ PM } & $150-60$ & 630 & 0 & 609 & 21 \\
\hline & $150-120$ & 810 & 0 & 697 & 113 \\
\hline \multirow[t]{2}{*}{ SM } & $150-60$ & 630 & 75 & 582 & 123 \\
\hline & $150-120$ & 810 & 75 & 595 & 310 \\
\hline \multicolumn{6}{|c|}{ Phosphorus (kg P ha $\left.{ }^{-1}\right)$} \\
\hline \multirow[t]{2}{*}{$\mathrm{TF}$} & $150-60$ & 197 & 0 & 138 & 59 \\
\hline & $150-120$ & 197 & 0 & 145 & 52 \\
\hline \multirow[t]{2}{*}{ PM } & $150-60$ & 197 & 0 & 138 & 59 \\
\hline & $150-120$ & 197 & 0 & 153 & 44 \\
\hline \multirow[t]{2}{*}{ SM } & $150-60$ & 197 & 15 & 135 & 77 \\
\hline & $150-120$ & 197 & 15 & 134 & 78 \\
\hline \multicolumn{6}{|c|}{ Potassium $\left(\mathrm{kg} \mathrm{K} \mathrm{ha}^{-1}\right)$} \\
\hline \multirow[t]{2}{*}{$\mathrm{TF}$} & $150-60$ & 375 & 0 & 612 & -237 \\
\hline & $150-120$ & 375 & 0 & 632 & -257 \\
\hline \multirow[t]{2}{*}{ PM } & $150-60$ & 375 & 0 & 706 & -331 \\
\hline & $150-120$ & 375 & 0 & 742 & -367 \\
\hline \multirow[t]{2}{*}{ SM } & $150-60$ & 375 & 173 & 660 & -112 \\
\hline & $150-120$ & 375 & 173 & 669 & -121 \\
\hline
\end{tabular}

a TF: traditional flooding; PM: plastic film mulching; SM: wheat straw mulching.

${ }^{b}$ The first value is for rice and the second is for wheat.

much lower than the total K outputs. Among the three treatments, net $\mathrm{P}$ balance in SM was higher than that in TF and PM, mainly due to the $\mathrm{P}$ addition from wheat straw $\left(15 \mathrm{~kg} \mathrm{Pha}^{-1}\right)$, whereas the $\mathrm{P}$ outputs $(134-$ $\left.153 \mathrm{~kg} \mathrm{Pha}^{-1}\right)$ were similar in the three treatments at two $\mathrm{N}$ rates. Mean $\mathrm{K}$ balance in SM $(-120 \mathrm{~kg}$ $\mathrm{K} \mathrm{ha}^{-1}$ ) was significantly greater than that in $\mathrm{TF}$ $\left(-247 \mathrm{~kg} \mathrm{~K} \mathrm{ha}^{-1}\right)$ and PM $\left(-349 \mathrm{~kg} \mathrm{~K} \mathrm{ha}^{-1}\right)$ across two $\mathrm{N}$ rates mainly because of considerable $\mathrm{K}$ inputs $\left(173 \mathrm{~kg} \mathrm{~K} \mathrm{ha}^{-1}\right.$ ) from wheat straw (Table 11). The above NPK balance results suggest that the same N, P and $\mathrm{K}$ rates to $\mathrm{R}-\mathrm{W}$ systems may not be appropriate for TF, PM and SM treatments for sustainability of the whole R-W systems.

\subsubsection{Changes in soil properties}

Some selected soil properties in the $0-10$ and 10$20 \mathrm{~cm}$ layers as affected by non-flooded mulching cultivation during 3 years of R-W systems are presented in Table 11 . Soil $\mathrm{pH}$ in $0-10 \mathrm{~cm}$ was significantly influenced by non-flooded mulching cultivation, whereas $10-20 \mathrm{~cm}$ soil $\mathrm{pH}$ was not affected after 3 years. SM and PM caused a distinct decline in the 0 $10 \mathrm{~cm}$ soil $\mathrm{pH}$ compared with TF. Soil organic carbon (OC) and total nitrogen (TN) contents were not significantly affected by non-flooded mulching cultivation in both soil layers, probably due to their very large pools in the soil. In contrast, soil AP in $0-10 \mathrm{~cm}(8.3-$ $\left.12.0 \mathrm{mg} \mathrm{kg}^{-1}\right)$ and $10-20 \mathrm{~cm}\left(2.9-4.1 \mathrm{mg} \mathrm{kg}^{-1}\right)$ layers and EK in the $0-10 \mathrm{~cm}\left(24.1-33.7 \mathrm{mg} \mathrm{kg}^{-1}\right)$ layer were significantly affected by non-flooded mulching cultivation, following the same sequence of $\mathrm{SM}>\mathrm{TF}$ and PM. Soil available $\mathrm{K}$ in the $10-20 \mathrm{~cm}\left(17.7-19.3 \mathrm{mg} \mathrm{kg}^{-1}\right)$ layer, however, was not significantly different among TF, PM and SM treatments. In general, most soil properties (except $\mathrm{pH}$ ) were improved or not influenced 
Table 11

Selected soil properties as affected by non-flooded mulching cultivation at normal $\mathrm{N}$ rate $\left(150-120 \mathrm{~kg} \mathrm{~N} \mathrm{ha}^{-1}\right)$ after three cycles of R-W systems ${ }^{\mathrm{a}}$

\begin{tabular}{cccccl}
\hline Mulching & $\begin{array}{l}\mathrm{pH}\left(\mathrm{H}_{2} \mathrm{O},\right. \\
1: 2.5)\end{array}$ & $\begin{array}{l}\mathrm{OC} \\
\left(\mathrm{g} \mathrm{kg}^{-1}\right)\end{array}$ & $\begin{array}{l}\mathrm{TN} \\
\left(\mathrm{g} \mathrm{kg}^{-1}\right)\end{array}$ & $\begin{array}{l}\mathrm{AP} \\
\left(\mathrm{mg} \mathrm{kg}^{-1}\right)\end{array}$ & $\begin{array}{l}\mathrm{EK} \\
\left(\mathrm{mg} \mathrm{kg}^{-1}\right)\end{array}$ \\
\hline $0-10 \mathrm{~cm}$ layer \\
TF & $7.6 \mathrm{a}$ & $16.0 \mathrm{a}$ & $2.21 \mathrm{a}$ & $8.7 \mathrm{ab}$ & $24.1 \mathrm{~b}$ \\
$\mathrm{PM}$ & $7.2 \mathrm{~b}$ & $16.4 \mathrm{a}$ & $2.24 \mathrm{a}$ & $8.3 \mathrm{~b}$ & $28.9 \mathrm{ab}$ \\
$\mathrm{SM}$ & $7.2 \mathrm{~b}$ & $16.9 \mathrm{a}$ & $2.22 \mathrm{a}$ & $12.0 \mathrm{a}$ & $33.7 \mathrm{a}$ \\
& & & & & \\
10-20 cm layer & & & & \\
TF & $7.8 \mathrm{a}$ & $11.3 \mathrm{a}$ & $1.17 \mathrm{a}$ & $2.9 \mathrm{~b}$ & $17.7 \mathrm{a}$ \\
$\mathrm{PM}$ & $7.6 \mathrm{a}$ & $11.5 \mathrm{a}$ & $1.20 \mathrm{a}$ & $3.6 \mathrm{ab}$ & $19.3 \mathrm{a}$ \\
$\mathrm{SM}$ & $7.6 \mathrm{a}$ & $12.0 \mathrm{a}$ & $1.42 \mathrm{a}$ & $4.1 \mathrm{a}$ & $19.3 \mathrm{a}$ \\
\hline
\end{tabular}

${ }^{a}$ Values within the same row at the same layer are not significantly different.

b TF: traditional flooding; PM: plastic film mulching; SM: wheat straw mulching.

by non-flooded mulching cultivation, particularly the SM treatment compared with TF treatment after three cycles of R-W rotation, suggesting that non-flooded mulching has no negative effects on soil fertility in the short term. In addition, it must be stressed that the available $\mathrm{K}$ contents in the two soil layers across three treatments were lower than in the original soil $(0-20 \mathrm{~cm})$, indicating a declining trend in soil available $\mathrm{K}$ under continuous $\mathrm{R}-\mathrm{W}$ systems. The changes observed in soil nutrient status, particularly $\mathrm{P}$ and $\mathrm{K}$ availability, were consistent with the apparent nutrient balances.

\section{Discussion}

\subsection{Crop growth, yields and nutrient uptake}

Rice is traditionally grown in submerged conditions with a stable water layer that maintains an anaerobic environment. Non-flooded mulching cultivation, as a new water-saving technology, significantly altered the rice growth environment through changes in soil water, temperature and nutrient status. For example, the $\mathrm{N}$ forms and even availability will change largely from TF (anaerobic) to non-flooded mulching (aerobic) condition. In the present study, PM increased the biomass accumulation and grain yield of rice, presumably due to increased soil temperature during the rice growing period, particularly at early tillering.
Higher soil temperatures from PM would have accelerated nutrient transformations (e.g. $\mathrm{N}$ ammonification and nitrification) and may have provided a better root growth environment. Thus PM enhanced root growth, tiller number (data not shown) and shoot biomass accumulation in this study. Shen et al. (1997) reported that plastic mulching cultivation produced larger and more vigorous root systems and improved early tillering due to higher temperatures compared with the traditional flooded system. According to the studies by Liang et al. (1999) and Wu et al. (1999), more white roots with higher biological activity were found during the whole growing period of rice under PM conditions compared with TF, suggesting that PM rice may have the potential to absorb more nutrients from the soil. This was confirmed by our results (Table 5).

In contrast, SM inhibited shoot biomass accumulation and grain yield of rice, probably due to a decline in soil temperature, particularly during the early growing period of rice. Lower soil temperatures limited the biological activity of rice roots and inhibited their capacity to absorb nutrients. According to a preliminary study by Hasegawa et al. (2001), the critical soil temperature for normal growth of rice roots ranged from 24 to $27^{\circ} \mathrm{C}$, which was similar to the soil temperature at $10 \mathrm{~cm}$ depth in our study (Table 2). In a soil-column study, Wang (2001) found that the growth and grain yield of rice in SM treatment were similar to those in TF and PM treatments when the soil temperatures in those treatments were the same, further indicating that soil temperature could be a major factor influencing the growth of rice mulched with straw. Meanwhile, $\mathrm{N}$ immobilization caused by the initial degradation of wheat residue with a wide $\mathrm{C} /$ $\mathrm{N}$ ratio would decrease soil available $\mathrm{N}$ (mineral $\mathrm{N}$ content) in the SM treatment (Rao and Mikkelsen, 1976). For example, we observed typical $\mathrm{N}$ deficiency symptoms in rice mulched with straw at tillering, suggesting a greater $\mathrm{N}$ requirement by rice in the SM treatment. As a result, SM prolonged the growth of rice since re-greening and tillering and led to a decrease in grain yield.

The residual effect of non-flooded mulching to preceding rice on wheat was another concern for whole-system productivity. The biomass accumulation, grain yield and nutrient uptake of wheat were significantly higher in SM treatment than in TF and 
PM treatments at reduced $\mathrm{N}$ rate $\left(60 \mathrm{~kg} \mathrm{~N} \mathrm{ha}^{-1}\right)$ but were similar at normal $\mathrm{N}$ rate $\left(120 \mathrm{~kg} \mathrm{~N} \mathrm{ha}^{-1}\right)$. Compared with the normal $\mathrm{N}$ rate, similar grain yields and nitrogen uptake of wheat were achieved at reduced $\mathrm{N}$ rate in the SM treatment. However, a reduction of $60 \mathrm{~kg} \mathrm{~N} \mathrm{ha}^{-1}$ led to a significant decline in grain yield and nutrient uptake of wheat in the TF and PM treatments. A rapid nitrate test on wheat at booting (data not shown) further indicated that basal $\mathrm{N}$ application was adequate to meet the wheat $\mathrm{N}$ requirement in the SM treatment while $\mathrm{N}$ topdressing was required in the TF and PM treatments. This meant that considerable extra $\mathrm{N}$ in the SM treatment was available in the wheat season. This can be explained on the basis of $\mathrm{N}$ re-mineralization from immobilized $\mathrm{N}$ due to $\mathrm{SM}$ to rice, or greater $\mathrm{N}$ availability in the soil due to lower $\mathrm{N}$ uptake in the SM treatment in the rice season. Aulakh et al. (2000) also reported residual effects of green manure on wheat yields in $\mathrm{R}-\mathrm{W}$ rotations. In a 4-year experiment, they found that the supply of nutrients through the integrated use of green manure $\left(20 \mathrm{Mg} \mathrm{ha}^{-1}\right)$ and fertilizer $\mathrm{N}\left(60 \mathrm{~kg} \mathrm{ha}^{-1}\right)$ in rice produced greater yields of rice and wheat while reducing the use of fertilizer $\mathrm{N}$ by $50 \%$ in rice and $25 \%$ in wheat. Prasad et al. (2002) also observed residual effects of green manure applied to rice on pod yields of groundnut following rice.

PM had the same or a relatively higher system productivity (total grain yields of rice plus wheat) compared with TF across two $\mathrm{N}$ levels due to the priming effects on rice yield. In contrast, system productivity in the SM treatment was lower than in the TF treatment although the system grain yield gap between SM and TF could be largely eliminated at reduced $\mathrm{N}$ rate in wheat. The nutrient management system in which all NPK fertilizers were applied once as basal application in the rice season under nonflooded mulching conditions, particularly in the SM treatment in the present study, would not be conducive to efficient use of nutrients (especially $\mathrm{N}$ ) and would need to be improved by further studies on R-W systems (Singh and Singh, 2001).

\subsection{Nutrient balance, system sustainability and application potential}

Apparent nutrient balances in the R-W systems showed that PM always led to less nutrient balances compared with TF, suggesting that soil fertility exhaustion could occur under PM conditions. Hu et al. (1999) reported an $8 \%$ decline in OC and TN in a paddy field under PM conditions. However, our results have not shown any decrease in soil OC, TN, AP or EK in the PM treatment (Table 11). The longterm effects of PM on soil fertility require much more attention in China as this cultivation practice is increasing in popularity in many areas of the country, especially in arid and semi-arid regions. In the SM treatment, higher net nutrient balances were found due to the return of wheat straw as mulch material compared with the TF treatment. From the viewpoints of nutrient balance and soil fertility, the SM production system may be more sustainable than the PM production system. In addition, the extra low soil $\mathrm{K}$ availability combined with negative $\mathrm{K}$ balance in the $\mathrm{R}-\mathrm{W}$ systems in the present study suggested that higher K inputs from fertilizer, straw or manure be necessary to sustain the high system productivity.

The potential for using non-flooded mulching cultivation depends firstly on economic factors, i.e. the difference between the income and the cost. It is quite clear that farmers will not adopt non-flooded mulching cultivation unless the system brings more net income than the traditional cultivation system. Thus, only when a comparable or higher system productivity was achieved without a significant increase in inputs have farmers tended to use this new water-saving cultivation method in R-W systems. On the other hand, the long-term environmental risks (i.e. greenhouse gas emission and nitrate leaching) of nonflooded mulching cultivation in R-W systems should also be taken into account (Liang et al., 2000). The TF system produced relatively stable grain yields of rice and wheat but needed large amounts of irrigation water. SM is good for sustainable material recycling and the succeeding wheat crop but at the cost of lower system productivity due to the decline in rice yields. Thus it is important to improve the SM system productivity through integrated nutrient management (e.g. larger $\mathrm{N}$ inputs to rice and smaller $\mathrm{N}$ inputs to wheat). In PM, the system productivity is comparable with, or relatively higher than that of TF, while the main problems in this system include the cost of plastic film, labour, and removal of residual plastic. In many mountain areas of China, low temperature and water shortage are two important stress factors 
that limit rice production in $\mathrm{R}-\mathrm{W}$ systems. The PM system is probably suitable for these mountain areas through the improvement of soil temperature and water conservation (Peng et al., 1999). The SM system, however, might be more suitable for those lowland regions where water and temperature conditions are less limiting.

\section{Acknowledgements}

We are grateful for generous financial support from the Major State Basic Research Development Programme of the People's Republic of China (project G1999011707), the Major Research Programme of the Chinese Ministry of Education (project 0112), and the National Natural Science Foundation of China (project 49801013).

\section{References}

Aulakh, M.S., Khera, T.S., Doran, J.W., Singh, K., Singh, B., 2000. Yields and nitrogen dynamics in a rice-wheat system using green manure and inorganic fertilizer. Soil Sci. Soc. Am. J. 64, $1867-1876$.

Bacon, P.E., 1987. Effect of nitrogen fertilization and rice stubble management techniques on soil moisture content, soil nitrogen status, and nitrogen uptake by wheat. Field Crops Res. 17, 75-90.

Bacon, P.E., Cooper, J.L., 1985a. Effect of rice stubble and fertilizer nitrogen management on wheat growth after rice. Field Crops Res. 10, 229-239.

Bacon, P.E., Cooper, J.L., 1985b. Effect of rice stubble and fertilizer nitrogen management techniques on yield of wheat sown after rice. Field Crops Res. 10, 241-250.

Bhuiyan, S.L., 1992. Water management in relation to crop production: case study on rice. Outlook Agric. 21, 293-299.

Fan, X., Zhang, J., Wu, P., 2002. Water and nitrogen use efficiency of lowland rice in ground covering rice production system in south China. J. Plant Nutr. 25 (9), 1855-1862.

Guerra, L.C., Bhuiyan, S.L., Tuong, T.P., Baker, R., 1998. Producing more rice with less water. SWIM Paper No. 5. International Water Management Institute (IWMI), Colombo, Sri Lanka, 19 pp.

Hasegawa, T., Fujimura, S., Shimono, H., Iwama, K., Jitsuyama, Y., 2001. Rice growth and development limited by root zone temperature. In: Morita, S. (Eds.), Proceedings of the Sixth Symposium of the International Society of Root Research. Published by Japanese Society for Root Research (JSRR), Nagoya, Japan, pp. 520-521.

Hu, F., Yang, M., Liang, Y., Liu, M., Chen, X., 1999. A study on fertility characteristics of paddy soils under plastic film mulching condition. In: Soil Committee of Jiangsu Province (Eds.), Soil Science Towards 21st Century (Jiangsu Vol.). Hehai University Press, Nanjing (in Chinese).

Jemison, J.M., Fox, R.H., 1988. A quick-test procedure for soil and plant tissue nitrate using test strips and a hand-held reflectometer. Commun. Soil Sci. Plant Anal. 19, 1569-1582.

Liang, Y.C., Hu, F., Yang, M.C., Zhu, X.L., Wang, G.P., Wang, Y.L., 1999. A study on high-yielding and water-saving mechanisms of upland rice mulched by plastic film. Sci. Agric. Sinica 31, 26-32 (in Chinese with English abstract).

Liang, Y.C., Hu, F., Shen, Q.R., Lu, S.H., Wu, L.H., Zhang, F.S., 2000. An overview of rice cultivation on plastic film mulched dryland. In: Studies on Plant Nutrition-Progress and Overview. China Agricultural University Press, Beijing, pp. 114-127 (in Chinese with English abstract).

Liu, X.J., Ju, X.T., Zhang, F.S., Chen, X.P., in press. Nitrogen recommendation using Nmin test and rapid plant tests in North China Plain. Commun. Soil Sci. Plant Anal.

Mao, Z., 2001. Water efficient irrigation and environmentally sustainable irrigated rice production in China. International Commission on Irrigation and Drainage. http://www.icid.org/ wat_mao.pdf.

Peng, S., Shen, K., Wang, X., Liu, J., Luo, X., Wu, L., 1999. A new rice cultivation technology: plastic film mulching. Int. Rice Res. Newslett. 24, 9-10.

Ponnamperuma, F.N., 1984. Straw as a source of nutrients for wetland rice. In: Organic Matter and Rice. IRRI, Los Banos, Philippines, pp. 117-136.

Prasad, R., Gangaiah, B., Aipe, K.C., 1999. Effect of crop residue management in a rice-wheat cropping system on growth and yield of crops and on soil fertility. Exp. Agric. 35, 427-435.

Prasad, P.V.V., Satyanarayana, V., Murthy, V.R.K., Boote, K.J., 2002. Maximizing yields in rice-groundnut sequence through integrated nutrient management. Field Crops Res. 75, 9-21.

Raison, R.J., 1979. Modification of the soil environment by vegetation fires, with particular reference to nitrogen transformation: a review. Plant Soil 51, 73-108.

Rao, D.N., Mikkelsen, D.S., 1976. Effect of rice straw incorporation on rice plant growth and nutrition. Agron. J. 68, 752-755.

Rasmussen, P.E., Collins, H.P., 1991. Long-term impacts of tillage, fertilizer, and crop residues on soil organic matter in temperate semi-arid regions. Adv. Agron. 45, 93-134.

SAS Institute, 1996. SAS User's Guide. SAS Institute, Inc., Cary, NC.

Schenk, M.K., 1998. Nitrogen use in vegetable crops in temperate climates. Hort. Rev. 22, 185-223.

Shen, K., Wang, X., Luo, X., 1997. Test and demonstration on wetcultivation with film mulching of rice. Hebei Agric. Sci. 5, 1822 (in Chinese).

$\mathrm{Si}, \mathrm{T}$, , 2000. Suggestion and discussion of several problems on water saving rice production in China. Irrig. Drainage 19, 3033 (in Chinese).

Singh, Y., Singh, B., 2001. Efficient management of primary nutrients in the rice-wheat system. In: Palit, K., Kataki (Eds.), The Rice-Wheat Cropping System of South Asia: Efficient Production Management. Food Products Press, An Imprint of the Haworth Press, pp. 23-85. 
Sparks, D.L., Page, A.L., Johnston, C.T., Summer, M.E. (Eds.), 1996. Methods of Soil Analysis. Part 3. Chemical Methods. SSSA Book Series No. 5. SSSA, Madison, WI, pp. 10851121.

Timsina, J., Connor, D.J., 2001. Productivity and management of rice-wheat cropping systems: issues and challenges. Field Crops Res. 69, 93-132.

Ueno, H., Yamanura, S., 1997. Nitrogen dynamics in papermulched paddy field fertilized with controlled-release coated urea by ${ }^{15} \mathrm{~N}$-method. In: Ando, T., et al. (Eds.), Plant Nutrition-For Sustainable Food Production and Environment. Kluwer Academic Publishers, Dordrecht, pp. 539-540.

Wang, J.C., 2001. Crop yields and nutrient dynamics impacted by different mulching styles in upland rice/wheat rotation systems. Ph.D. Dissertation. China Agricultural University (in Chinese with English abstract).
Wu, B., Xie, X. (Eds.), 1985. Wet-cultivation Technology for Rice. Agricultural Press of China (in Chinese).

Wu, L.H., Zhu, Z.R., Liang, Y.C., Shi, W.Y., Zhang, L.M., 1999. A high-yielding, water-saving and fertilizer-saving cultivation technique for rice mulched by plastic film under dry land condition. J. Zhejiang Agric. Univ. 25, 41-42 (in Chinese with English abstract).

Zhao, Q., Xiao, M., 1982. Upland rice cultivation technique under plastic film mulching in Northeast region of Japan. J. Niaoning Agric. Sci. (4), 52-56 (in Chinese).

Zheng, J.G., 2000. Rice-wheat cropping system in China. In: Hobbs, P.R., Gupta, R.K. (Eds.), Soil and Crop Management Practices for Enhanced Productivity of the Rice-Wheat Cropping System in the Sichuan Province of China. Rice-Wheat Consortium Paper Series No. 9. Rice-Wheat Consortium for the Indo-Gangetic Plains, New Delhi, pp. 1-10. 